\title{
ANALYSIS OF THE FORMS OF PLACEMENT OF THE ORPHANS AND DEPRIVED OF PARENTAL CARE CHILDREN AND ITS EFFECTIVENESS IN UKRAINE
}

\author{
Svitlana MYKOLUK ${ }^{1}$, \\ Ternopil National Economic University, Ukraine
}

\begin{abstract}
The purpose. This article is devoted to the systems analysis of theoretical and practical aspects of forming of social security system of orphans and children deprived of parental care. Methodology. Covered a topical issue - placement of the orphans and deprived of parental care children. Characterized each form of the children placement emphasizing their fundamental difference and problem questions, consequences and lacks of such determination, are lighted up. Results. Offered a new approach to the forms of the children placement. Modern realities of the state development need considerable rethinking of essence of social security of children, and accordingly raising of new tasks which this system is called to decide, and mechanisms of realization of social security of children, which must be adequate to the markets conditions. Essence and functions of population social security of orphans and children deprived of parental care, are analyzed in the article. Practical meaning. Analysis of management activity in the field of social arrangement of children tells that the main its result is the arrangement of orphans and children deprived of parental care into the different forms of arrangements (adoption, guardianship (trusteeship), foster home, orphanage of family type, care home). We offer to consider the process of quality estimating with help of indicators of efficiency in depends on the priority in arrangement form of child (efficiency of management activity in the questions of adoption $\left(E_{a d}\right)$, efficiency of management activity in the questions of guardianship (trusteeship) $\left(E_{g}\right)$, efficiency of management activity in the questions of foster homes creation $\left(E_{f h}\right)$, efficiency of management activity in the questions of creation family type orphanage, $\left(E_{c t t o}\right)$ efficiency of management activity in the questions of care homes creation $\left(E_{c h c}\right)$ and general efficiency of management activity in the field of social arrangement of children $\left(E_{\text {arr }}\right)$. Value/originality. This approach makes it possible to improve the oversight function of the regional administration for further planning and adjustments of the management activities effectiveness indicators in the region.
\end{abstract}

Key words: adoption, guardianship, fostering, family-type orphanage, boarding school, management activities, effectiveness.

JEL Classification: J12, J13, O35, 038

\section{Introduction}

Today in Ukraine there is no comprehensive analysis of the state care forms for orphans and children deprived of parental care. Similar studies have been made in the works of scholars, such as V. Chippolino, I. Pesch, A. Gubanova, N. Ryzhyi, N. Nizhnik and others. However, scientists have worked in the conventional theoretical aspect, illuminating just certain nuances of family forms for orphans and children deprived of parental care. This is the reason why the level of the scientific researches remain low and does not meet the requirements of the time. A. Gubanova considers the adoption as the most preferred form of the existing family types for children (Gubanova, 2011). We are not opposed to such approval, but there are doubts about the other existing family types for children. N. Rudyi pays special attention to the guardianship (care) in family types for children and considers it as one of the major family forms, because the family ties are retained (Rydyi, 2011). In our opinion, this is not exactly the right position, because this form of the placement does not match the typical family model. We offer to take a critical look at the forms of children placement and find out if they all have the right to be called as "family".

\section{Analysis of the forms of government children}

The obligation to take care of every orphaned child, in accordance with the Ukrainian Constitution, is the responsibility of State (The Constitution of Ukraine, 1996). The guardianship authorities are engaged in the placement of such children. Consider the current form of governmental placement of orphans and children deprived of parental care (fig. 1): family forms of placement (adoption, guardianship (care), foster care and family-

\footnotetext{
Corresponding author:

${ }^{1}$ Department of Engineering Management, Ternopil National Economic University.

E-mail: mukolyk_s@mail.ru
} 
type orphanage) and institutions for orphans and children deprived of parental care (medical, training, educational and other institutions for children) (The Law of Ukraine on January 13, 2005, the number 2342).

Despite the common name "family forms", which actually means the education of children in the family, each of these forms differ from each other both on the legal and organizational grounds. To understand the fundamental difference, consider every form of family placement of the children.

Undoubtedly, the best of all existing forms of family placement of children is adoption of a child rights-native (Resolution of the Cabinet of Ministers of Ukraine on October 8, number 905). Only this form of the placement meets all existing "interests of the child" and deprives the child the status of orphan or child deprived of parental care. Adoption creates between the adoptive parents and the child mutual obligations and rights provided by the Family Code of Ukraine for children and their biological parents. This means that adoption is a special form of child protection, which establishes the relationship between the child and the people, who are not his own father or mother. It is also important, that the adoption gives the child a real family. Considering the above, it is necessary to legalize the concept of "interests of the child" as one, that excludes the priority of interests of the adoptive parents to the interests of the child. The main thing with the adoption is the creation of conditions for the full development of the child, the child's education, preparation for independent life and work. It is important, that from the time, when the child has been adopted, it acquires personal property and non-property rights of the adopted child (in later life and among his children and grandchildren) and the adopter (including his close relatives by birth). We consider it appropriate to add to the list of documents for the adoption also notarized consent to the adoption of a child from grandparents of the adopted children (parents of the adopters).

Particular attention should be given to inter-country adoptions. The situation, that exists in this area requires a clear legal regulation and control. National interests of Ukraine corresponds to joining the Hague Convention on Protection of Children and Cooperation in Respect of Intercountry Adoption of 1993. After all, only close cooperation between the country of origin of the adoptive parents and country of origin of the child, you can protect the rights of the adopted child. It should be noted, that the secrecy of adoption in Ukraine continues to this day, in violation of the UN Convention on the Rights of the Child (adopted children have the right to know their biological parents). Despite a number of shortcomings of the current legislation of Ukraine, we believe, that adoption can only be called as the form of family placement of children.

The most common form of the placement of orphan or child deprived of parental care in Ukraine is guardianship (Resolution of the Cabinet of Ministers of Ukraine on October 8, number 866). Ukrainian legislation determined, that the guardian or trustee appointed mainly people in the family, relative of the ward: grandparents, at least - uncles and aunts of children. Thus, the child is brought up in a family environment, keeping blood ties. We believe, that this form of the placement of the child should be called exactly guardianship and not the family. Family forms of placement suggests the presence of parents (father, mother). An exception may be the custodial family, when the guardian is not a relative of the child. In this case, this guardianship should be considered as a prototype of a foster family.

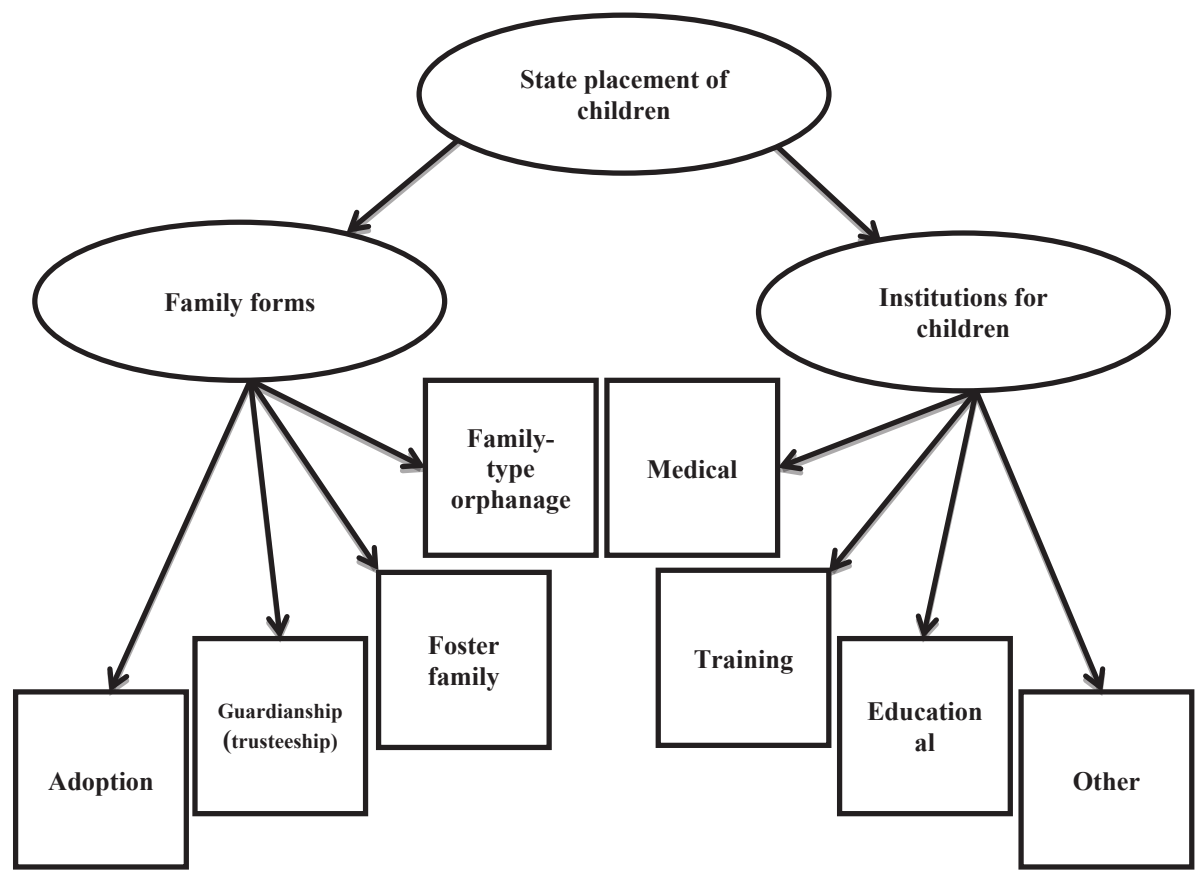

Fig. 1. The current forms of the State placement of children 
A child under guardianship (trusteeship) retains the status of orphan or child deprived of parental care, and have all social benefits. As with adoption, the law does not set a limit of the number of children, that can be arranged under the guardianship (trusteeship) in one family. In Ukraine, since 2002, began an intensive creation of foster families and family-type orphanages. Consider these forms of child's placement.

Foster family - a single person or family, who voluntarily, for certain monthly payments from the state take for bringing up and to live together between one and four orphans or children deprived of parental care.

Foster family - a single person or family, who voluntarily, for certain monthly payments from the state provides education and living together between one and four orphans or children deprived of parental care. Between the agency of trusteeship and guardianship and the foster parents must be sign an agreement on the duties and responsibilities for the common residence, education and maintenance of children in the family of adoptive parents. (Resolution of the Cabinet of Ministers of Ukraine on April 26, 2002, number 565)

The family type children's home (orpahanage) - single family, that voluntarily, for certain monthly payments from the state provides education and living together for at least five orphaned children or children deprived of parental care. The total number of children in such family can not exceed 10 people (including own children of the adoptive parents). The placement of children in family-type orphanage is only possible on the basis of the decision of the guardianship authority, which provides for the mutual responsibilities and obligations of the parties. (Resolution of the Cabinet of Ministers of Ukraine on April 26, 2002, number 564).
Thus, in foster homes and orphanages there are conditions close to normal family life. Children, during the stay in a foster family or family-type children's home, retain the status of orphan or child deprived of parental care, and enjoy all the social benefits. In our opinion, these forms of care for orphans can not be called as family, because they, unlike adoption and guardianship, are temporary and assume no legal obligation after the termination of the contract (decision) cohabitation, education and maintenance of orphans and children deprived of parental care. We believe, that the foster families and familytype orphanages should be attributed to the residential institutions of family forms of education (mini-boarding). A child, who is left without parental care, temporarily can be arranged with the decision of the guardianship authority in institutions for orphans and children deprived of parental care. Placing the child in such institution does not exempt public entities from the obligation to continue work on the implementation of the rights of the child in the family.

So, according to the above said arguments, we offer our vision of the names of the sovereign-governmental forms of care for orphans and children deprived of parental care (Figure 2).

\section{The effectiveness of administrative activity sphere of placement of children}

The main result of the work of state structure is to achieve its main goal: placement of orphans and children deprived of parental care in family-based education forms (adoption, guardianship (trusteeship), foster care, family-type orphanage. Therefore, management activities are aimed at the realization of this objective. Given that the purpose of the object that receives a management decision and is aimed at

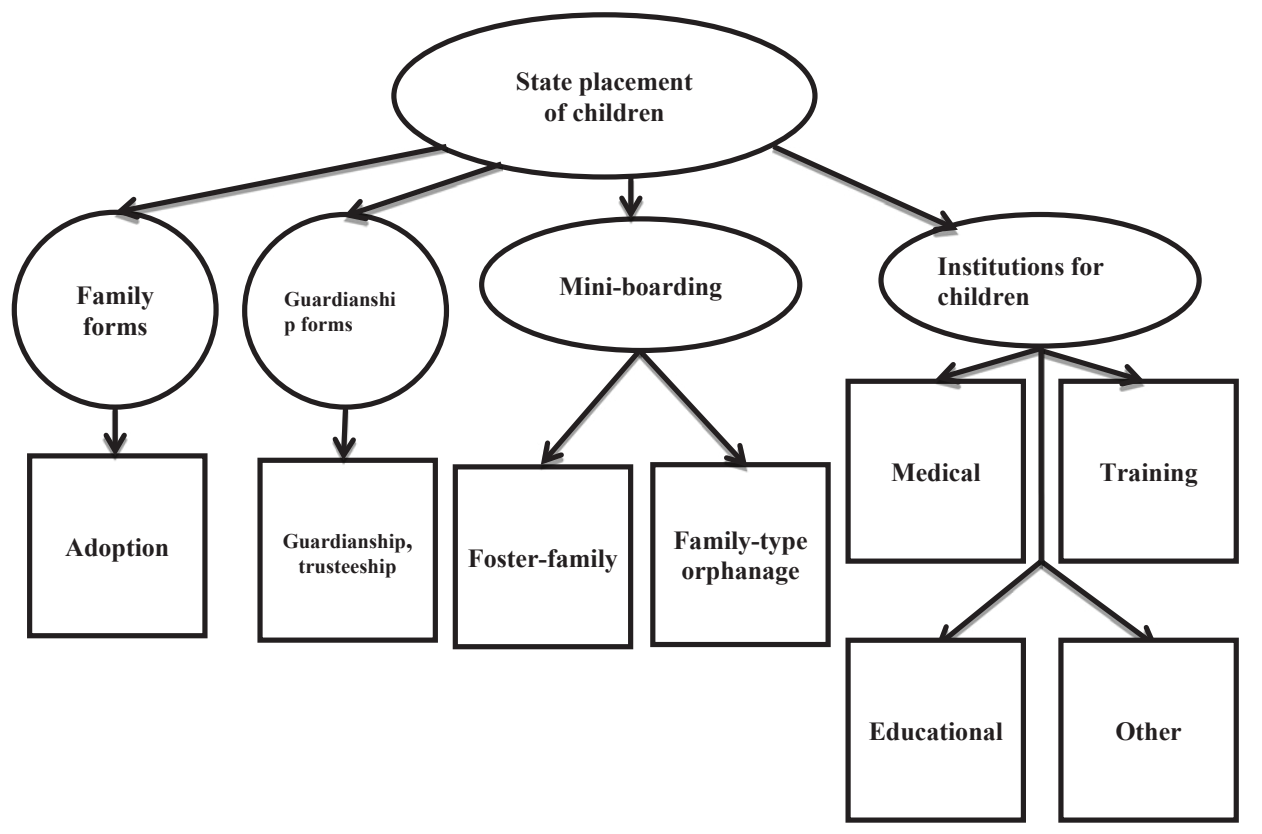

Fig. 2. Forms of the state placement of children (proposed) 
increasing the number of placement of children - orphans in family forms of education we can talk about social efficiency of management. Therefore, management activities are aimed at the realization of this goal. This means, that the main purpose of the object, that receives a management decision, is one and it aims to increase the number of placement of orphans in family forms of education, so we can talk about social efficiency of management.

Social efficiency of the management shows the extent to which demand for the service is met. Based on the analysis perform basic management tasks on the placement of children in various forms of education, in our opinion, can be assessed results of administrative activity. The evaluation process in this case is to determine the effectiveness of management activities, depending on the priority forms of children's placement. The evaluation result will determine, how efficiently and effectively the structure of management worked and were the main goals of management for a certain period achieved.

So we offer a variety of formulas, using which it is possible to assess the effectiveness of management activities, depending on the form of the placement of the child.

We suggest the following method to evaluate the effectiveness of management activities in the field of social placement of children. So on the primary accounting of services for children is the defined number of orphans and children deprived of parental care. It is important to note, that not all status children, in accordance with the applicable law, suitable for all forms of placement. With the number of children who are adopted, and the number of children available for adoption, you can determine the effectiveness of the structure of administrative activity in matters of adoption.

$$
E_{\text {aa }}=\frac{C a d}{C a v} \times 100, \%
$$

Eaa - effectiveness of administrative activity in matters of adoption, $\%$,

Cad - number of adopted children,

Cav - number of children available for adoption.

It is clear, that the higher the percentage of efficiency of administrative activity in matters of adoption is, the more children will be adopted and the mechanism of administrative activity would work better. Thus, according to the proposed formula (1), with the qualitative work of the management's subjects, the effectiveness of administrative activity in matters of adoption should be close to $100 \%$.

There are four possible forms of placement of children: guardianship, foster care, family-type orphanage, boarding schools. We believe, that the same method can be arranged to calculate the ratio of children to the different forms of education of the total number of children who are registered. This analysis will allow to calculate the percentage of administrative activity of the structure and to determine its effectiveness in terms of forms of children 's placement:

$$
E_{g}=\frac{C_{g}}{C a} \times 100, \%
$$

$\mathrm{Eg}$ - effectiveness of administrative activity in matters of guardianship (trusteeship), \%
$\mathrm{Cg}$ - number of children, that are arranged under the guardianship,

$\mathrm{Ca}$ - number of children, who are in a primary account.

$E_{f h}=\frac{C f}{C a} \times 100, \%$

Efh - effectiveness of administrative activity in matters of establishment of foster homes, \%,

Cf - number of children who have arranged to foster families,

$\mathrm{Ca}$ - the number of children, who are in the primary account.

$$
E_{\text {efth }}=\frac{C c h}{C a} \times 100, \%
$$

Eefth - effectiveness of management activities on the establishment of family-type homes, \%,

Cch - the number of children, who had set up in children's homes,

$\mathrm{Ca}$ - the number of children, who are in the primary account.

$$
E_{b s}=\frac{C b i}{C a} \times 100, \%
$$

Ebs - effectiveness of administrative activity in matters of boarding schools, \%,

$\mathrm{Cbi}$ - the number of children, who are organized in boarding institutions,

$\mathrm{Ca}$ - the number of children, who are in the primary account.

\section{Conclusions}

Thus, the proposed formulas $(2,3,4)$ for calculation of the efficiency of administrative activity in matters of placement of children into care (guardianship), the creation of foster families and family-type homes will allows to analyze the effectiveness of the activity of the control subjects in social arrangements for children. It is clear that the highest rate should be according to the formula (2), as the placement of children into guardianship, usually retains the family relationships of the child (guardian - grandfather, grandmother) is a priority for the placement of the child in foster families or family-type orphanages.

Equation (5) efficiency of administrative activity in matters of placement of children in boarding institutions shows the percentage of children, placed in boarding school for children, who are in the primary account on the Service for Children. It is clear, that this indicator should be the lowest, because the placement of the child in a boarding school is the worst for the child and disgraceful management solution for control subjects.

Given the fact, that the end result of management activity spheres of social organization aimed at the placement of children in the family forms of education so that you can evaluate the effectiveness of management activities in the field of social placement.

Thus, we propose to evaluate the effectiveness of management activities in the field of children's social placement with the following formula (6):

$$
E_{s p}=\frac{C f e}{C a} \times 100, \%
$$


Esp - effectiveness of management activities in the area of social placement of children, $\%$

$\mathrm{Cfe}$ - number of children, that are arranged in the forms of family education,

$\mathrm{Ca}$ - number of children, who are in the primary account.

The proposed approach to evaluate the effectiveness of management activity areas of social placement in the region, make it possible to provide a control function to further planning and adjustment of these parameters.

The problem of child abandonment is not new. In each country the problem of the placement of such children is solved differently, given the specificity and the mentality of the country. Even in the post - Soviet countries there are significant differences. For example, the number of children in foster care in the different countries are not the same (in Russian adoptive families can bring up to eight children, in Ukraine - up to four).
There are differences in the definition of the status of children's homes and foster families (in Russian familytype orphanage is an institution, a legal entity, and in Ukraine - it is a family). Although this problem has a social character, it is not sufficiently investigated. This is evidenced with the absence of the index in the Universal Decimal Classification (UDC). Questions for childhood are located in different sections of the classifier. We consider it to appropriate for the development of scientific research in this area and for the practical solution of a number of problems in the area of care for orphans and children deprived of parental care, to provide the recommendations of the International Federation for Information and Documentation (Federation Internationale de Documentation) to amend the UDC supplemental index "The child. Social orphanhood. State system of placement of children".

\section{References}

Gubanova V.V. (2011) Organizational - legal regulation of adoption in Ukraine: Author. Diss. On receipt of scientific. PhD degree. jurid. Sciences: spec. 12.00.07 "Administrative law and process, financial law, information law” - Kiev, 17 p.

Rydyi N.Y. (2011) Institute of guardianship and trusteeship in Ukraine: historical - legal research: the Author. diss. to produce scientific. PhD degree. jurid. Sciences: spec. 12.00.01 "Theory and History of State and Law, History of Political and Legal disciple" - Lviv, $22 \mathrm{p}$.

The Constitution of Ukraine, 1996. - 80 p.

The Law of Ukraine "On ensuring organizational and legal conditions for social protection of orphans and children deprived of parental care" (as amended) on January 13, 2005, the number 2342.

Resolution of the Cabinet of Ministers of Ukraine "On Approval of the Procedure for adoption activities and supervise the observance of the rights of adopted children" (as amended) on October 8, 2008, number 905.

Resolution of the Cabinet of Ministers of Ukraine "Issues of the activities of the guardianship authorities, associated with the protection of the rights of the child" (as amended) on September 24, 2008 number 866.

Resolution of the Cabinet of Ministers of Ukraine "On Approval of the foster family" on April 26, 2002, number 565. Resolution of the Cabinet of Ministers of Ukraine "On Approval of the family-type orphanage" on April 26, 2002 number 564.

\section{Светлана МЫколюк}

\section{АНАЛИЗ ФОРМ УСТРОЙСТВА ДЕТЕЙ-СИРОТ И ДЕТЕЙ, ЛИШЕННЫХ РОДИТЕЛЬСКОЙ ОПЕКИ И ЕЕ ЕФЕКТИВНОСТЬ В УКРАИНЕ}

Аннотация. Цель работы. Статья посвящена системному анализу теоретических и практических аспектов формирования системы социального устройства детей-сирот и детей, лишенных родительской опеки. Методика. Освещена чрезвычайно актуальная проблема современности - устройство сирот и детей, лишенных родительской опеки. Охарактеризованы все формы устройства ребенка, подчеркнуто их принципиальное отличие друг от друга. Освещены проблемные вопросы, последствия и недостатки такого устройства. Результат. Предложен новый подход к формам устройства ребенка. Современные реалии развития государства требуют значительного переосмысления сущности социального устройства детей, а соответственно, постановки новых задач, которые призваны решать эта система, и механизмов осуществления социального устройства детей, которые должны быть адекватные рыночным условиям. В статье раскрываются сущность и функции социального устройства детей-сирот и детей, лишенных родительской опеки. Практическое значение. Анализ управленческой деятельности сферы социального устройства детей говорит о том, что основным ее результатом есть устройство детей-сирот и детей, лишенных родительской опеки в разные форму устройства (усыновление, опека (попечительство), приемная семья, детский дом семейного типа, интернатное учреждение). Процесс качественной оценки управленческой деятельности предлагаем рассчитывать с помощью показателей эффективности в зависимости от приоритетности форм устройства ребенка (эффективность управленческой 
деятельности в вопросах усыновления $\left(E_{y c}\right)$, эффективность управленческой деятельности в вопросах опеки (попечительства) $\left(E_{o}\right)$, эффективность управленческой деятельности в вопросах создания приемных семей $\left(\underline{E}_{n c}\right)$, эффективность управленческой деятельности в вопросах создания детских домов семейного типа ( $\left.E_{\text {дьст }}\right)$, эффективность управленческой деятельности в вопросах интернатных заведений $\left(E_{n}\right)$ и общую эффективность управленческой деятельности в сфере социального устройства детей $\left(E_{y}\right)$. Значение/оригинальность. Этот подход позволяет улучшить контрольную функцию органам регионального управления с целью дальнейшего планирования и корректирования показателей эффективности управленческой деятельности регионов. 